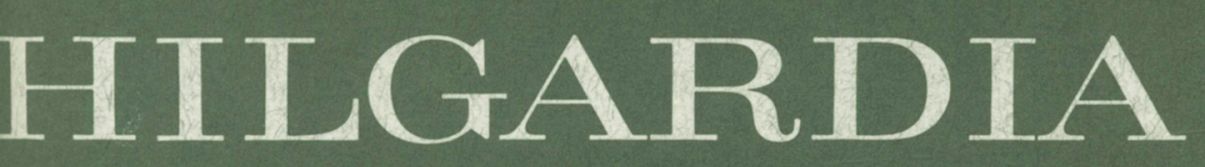

A JOURNAL OF AGRICULTURAL SCIENCE PUBLISHED BY THE CALIFORNIA AGRICULTURAL EXPERIMENT STATION

Volume 35, Number $19 \cdot$ October, 1964

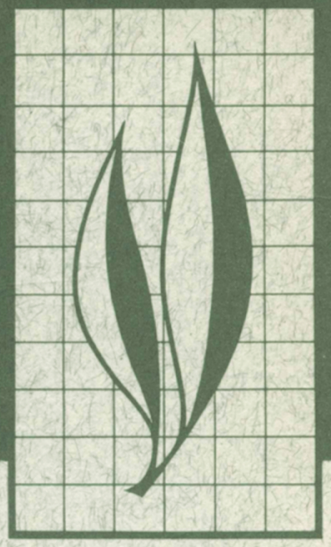

Evaluation of Concentrate and Dilute Ground Air-Carrier and Aircraft Spray Coverages

W. W. Kilgore, W. E. Yates, and J. M. Ogawa

\title{
Susceptibility of Almond Leaf to Coryneum Blight, and Evaluation of Helicopter Spray Applications for Disease Control
}

J. M. Ogawa, W. E. Yates, and W. W. Kilgore 


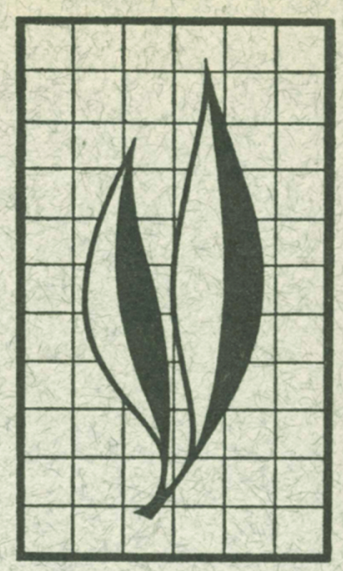

\section{Evaluation of Concentrate and Dilute Ground Air-Carrier and Aircraft Spray Coverages}

The fungicide captan was applied to almond trees for the control of Coryneum blight (Coryneum beijerinckii Oud.) and Hendersonia leaf blight (Hendersonia rubi Sacc.). Applications were made by ground air-carrier sprayers (low- and high-volume gallonages), by helicopter, and by fixed-wing aircraft. The extent of disease control was determined for each method of application and compared to captan deposits on leaves and on glass microscope slides placed in the trees at various levels.

\section{Susceptibility of Almond Leaf to Coryneum Blight, and Evaluation of Helicopter Spray Applications for Disease Control}

Coryneum beijerinckii conidia germinated equally well on both surfaces of almond leaves. The underside of leaves was more prone to infection than the upper side and deposits on both surfaces were required for effective disease control. Helicopter spray applications with captan gave excellent disease control, provided the spray droplet size and air speed were reduced from those normally used in commercial helicopter spray applications. The finer spray droplets and slower helicopter speed resulted in considerably more captan deposit on both surfaces of leaves and glass slides. The amount of this deposit was determined by chemical analyses and its fungitoxicity was determined by bioassay with conidia of C. beijerinckii.

\section{THE AUTHORS:}

W. W. Kilgore is Lecturer, Department of Food Science and Technology, and Assistant Biochemist in the Agricultural Toxicology and Residue Research Laboratory, Davis; W. E. Yates is Associate Professor of Agricultural Engineering and Associate Agricultural Engineer in the Experiment Station, Davis; J. M. Ogawa is Associate Professor of Plant Pathology and Associate Plant Pathologist in the Experiment Station, Davis. 


\section{Evaluation of Concentrate and Dilute Ground Air-Carrier and Aircraft Spray Coverage ${ }^{1}$}

\section{INTRODUCTION}

INCREASED INTEREST in the use of concentrate sprays applied at low gallonage by aircraft and by ground air-carrier sprayers has created a need for more information about the extent of disease control and coverage efficiency of such methods. Concentrate spray applications applied by ground sprayers for almond (Prunus amygdalus Batsch.) disease control have been tested with favorable results by Ogawa and Yates
(1962), ${ }^{2}$ but aircraft applications have not been as promising (O'Reilly, 1957). The studies reported here were undertaken to explain the failure of aircraft spraying and the success of groundequipment spraying by comparing the extent of disease control with the pattern and amount of chemical deposited on the host by the two methods of applications.

\section{MATERIALS AND METHODS}

\section{Chemical used and Application Time}

A single spray of 50 per cent captan (N-trichloromethyl-thio-4-cyclohexene1,2-dicarboximide) was applied to the same almond (cultivar Drake) orchard at petal-fall (1961) and 1 week after petal-fall (1962). Timing of the applications and chemical used were based on unpublished data on Coryneum blight collected by W. H. English and J. M. Ogawa (University of California, Davis) and on a publication on Hendersonia leafblight by Ogawa, Wilson, and English (1959).

Table 1 shows the application rate, weather conditions, and time of each treatment.

\section{Spraying Procedures and Equipment}

\section{1}

Standard High-volume (Dilute) Ground Application. The ground applications were made with a John Bean sprayer (Model $500 \mathrm{CP}$ ) which utilizes a vane axial blower (38-inch diameter) and develops a total air flow of 67,000 cubic feet per minute ( $\mathrm{cfm}$ ). The type, number, and location of nozzles used were selected to obtain the desired atomization, distribution, and application rate. Forty hollow-cone nozzles (Whirlmist type, $1 / 4$ A-5 nozzle body) were used, thirty with $1 / 8$-inch orifices and ten with $3 / 16$-inch orifices. Application was made with a nozzle pressure of 80

${ }^{1}$ Submitted for publication July 12, 1963.

2 See "Literature Cited" for citations referred to in the text by author and date. 
pounds per square inch (psi), spraying approximately 58 gallons per minute, at a forward speed of 2.5 miles per hour $(\mathrm{mph})$. The trees in the orchard were on a 24-foot square spacing, and the spray mixture contained 10 pounds of 50 per cent captan in 500 gallons of water. with 0.194-inch orifices were directed downward and operated at a spray pressure of $76 \mathrm{psi}$. The aircraft was flown between the rows at 80 to 85 mph, 10 to 15 feet above the tree-tops. The spray mixture contained 24 pounds of 50 per cent captan in 75 gallons of water.

TABLE 1

METHODS AND CONDITIONS OF APPLICATIONS

\begin{tabular}{|c|c|c|c|c|c|}
\hline \multirow{2}{*}{ Method and year of application } & \multicolumn{3}{|c|}{ Weather } & \multicolumn{2}{|c|}{ Application rate } \\
\hline & $\begin{array}{l}\text { Average wind } \\
\text { velocity }\end{array}$ & Temperature & $\begin{array}{l}\text { Relative } \\
\text { humidity }\end{array}$ & $\begin{array}{l}\text { Amount of } \\
\text { spray per acre }\end{array}$ & $\begin{array}{c}\text { Amount of } \\
\text { captan per acre }\end{array}$ \\
\hline $\begin{array}{l}\text { 1961: } \\
\text { fixed-wing aircraft. } \ldots \ldots \ldots \ldots \ldots \ldots \\
\text { high volume (dilute) ground sprayer.. } \\
\text { low volume (concentrate) ground } \\
\quad \text { sprayer. } \ldots \ldots \ldots \ldots \ldots \ldots \ldots \ldots \ldots \ldots\end{array}$ & $\begin{array}{l}\text { miles per hour } \\
2.4 \\
2.7 \\
\\
3.5\end{array}$ & $\begin{array}{l}{ }^{\circ} F \\
49 \\
54 \\
62\end{array}$ & $\begin{array}{c}\text { per cent } \\
\quad 91 \\
83 \\
\\
\quad 68\end{array}$ & $\begin{array}{c}\text { gallons } \\
30.7 \\
467.0 \\
\\
24.0\end{array}$ & $\begin{array}{l}\text { pounds } \\
4.9 \\
4.67 \\
\\
3.84\end{array}$ \\
\hline $\begin{array}{l}1962: \dagger \\
\text { helicopter aircraft...... } \\
\text { fixed-wing aircraft. } \ldots \ldots \ldots \ldots \ldots \ldots \ldots \ldots \ldots \\
\text { high volume (dilute) ground sprayer.. }\end{array}$ & $\begin{array}{r}5.2 \\
9.1 \\
11.1\end{array}$ & $\begin{array}{l}50 \\
56 \\
57\end{array}$ & $\begin{array}{l}78 \\
75 \\
70\end{array}$ & $\begin{array}{r}18.3 \\
15.3 \\
435.0\end{array}$ & $\begin{array}{l}3.6 \\
3.0 \\
4.3\end{array}$ \\
\hline
\end{tabular}

* March 9, from 7:30 A.M. until 12:30 P.M.

† March 19, from 7:30 A.M. until 9:35 A.M.

Low-volume (Concentrate) Ground Application. The above sprayer was modified by changing the size, type, and number of nozzles. For these tests, 22 hollow-cone nozzles (Monarch type, F-97-9.0) with 0.035-inch orifices were arranged to produce a discharge pattern similar to the high-volume application. Application was made with a nozzle pressure of $80 \mathrm{psi}$, spraying 3.0 gallons per minute, at a forward speed of $2.5 \mathrm{mph}$. The spray mixture contained 16 pounds of 50 per cent captan in 50 gallons of water.

Fixed-wing Aircraft Application. A Stearman biplane with conventional agricultural equipment was used for the fixed-wing application. The aircraft was equipped with a 450 horsepower engine, a spray pump driven by a "V" belt drive from the generator pad, and a trailing edge boom mounted 8 inches behind and 5 inches below the rear edge of the lower wing. Thirtyfour hollow-cone nozzles (Whirljet type, 1/8 B8; Spraying Systems Co.)

\section{2}

\section{Standard High-volume (Dilute)} Ground Application. The same air-carrier sprayer was also used for the 1962 experiments. This year the sprayer was fitted with thirty-six hollow-cone nozzles (Whirlmist type, 1/4 A-5 nozzle bodies) ; twelve with $3 / 16$-inch orifices, six with $1 / 8$-inch orifices, six with $3 / 32$ inch orifices, and twelve with 5/64-inch orifices. Application was made with a nozzle pressure of 80 psi, spraying 38 gallons per minute, at a forward speed of $1.8 \mathrm{mph}$. The spray mixture contained 10 pounds of 50 per cent captan in 500 gallons of water.

Fixed-wing Aircraft Application. A Stearman biplane similar to the one used for the 1961 experiments was also used for the 1962 tests. This aircraft was equipped with a 450 horsepower engine, a spray pump driven by a 20 inch wooden windmill, and a spray boom mounted 5 inches behind the trailing edge of the lower wing. Thir- 
ty-four hollow-cone nozzles (Vapor Spray Co.) with 5/32-inch orifices were directed downward and operated at a spray pressure of 60-65 psi. The aircraft was flown between the rows at 85 to $90 \mathrm{mph}, 5$ to 10 feet above the tree-tops. The spray mixture contained 24 pounds of 50 per cent captan in 60 gallons of water.

Helicopter Application. A Bell helicopter (Model 47G-2) fitted with agricultural spray equipment was used for this test. The aircraft was equipped with a belt-driven spray pump, and a 33 -foot spray boom. Forty-one hollowcone nozzles (disc type with a 45 core and a 5/64-inch orifice; Spraying Systems Co.) were directed downward from the boom and operated at a spray pressure of 45 psi with a flow rate of 26 gallons per minute. The forward speed was reduced to $25 \mathrm{mph}$ to increase the turbulence and circulation of the air wake behind the helicopter in an effort to improve the deposits and coverage. Flight was 5 to 10 feet above the tree-tops, with the flight path between the rows. The spray mixture contained 24 pounds of 50 per cent captan in 60 gallons of water.

\section{Degree of Infestation}

Coryneum blight was identified by the shot-holing and/or dark circular lesions on leaves and fruits, and Hendersonia leaf blight by the dead leaves on the trees. No other disease present in the test plots produced symptoms which could be confused with these two diseases.

\section{Captan Deposits and Analytical Procedures}

Direct information on the type of spray coverage was obtained by quantitative analysis of captan deposits on leaf samples and on glass microscope slides placed in the trees. In order to obtain sufficient data for deposits on the upper and lower surfaces, two microscope slides were taped back to

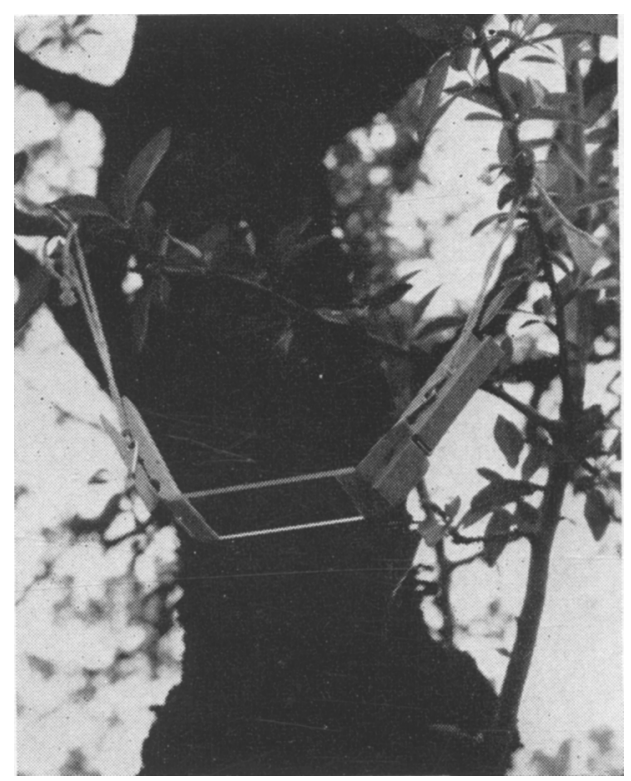

Fig. 1.-Microscope slides suspended in trees.

back and suspended in a horizontal position in the test trees (fig. 1). After spraying, the slides were removed and separated for deposit analysis. In 1961, when the standard high-volume ground application was compared to the fixedwing aireraft application and to the lowvolume ground application, twelve sets of double slides were placed in each of three trees in a single row, six trees apart, for each application. In 1962, when the fixed-wing aircraft, helicopter, and standard high-volume ground applications were compared, eighteen sets of double slides were placed in each of three central trees of each treatment. In most instances, nine sets were placed in the upper half and nine sets in the lower half of each test tree. After the applications were made and the deposits had dried, the slides were removed from the trees and stored for subsequent extractions and analyses.

Spray deposits on the slides and leaves were removed by several successive extractions with benzene. The extracts were then analyzed for captan by the method described by the California Spray-Chemical Corporation (1960). 


\section{RESULTS AND DISCUSSION}

\section{Experiments in 1961}

Deposits on Microscope Slides. Table 2 data indicate that the two types of ground applications deposited approxi- mately the same quantity of chemical on the microscope slides, irrespective of their positions in the trees. Although higher deposits were present on the top
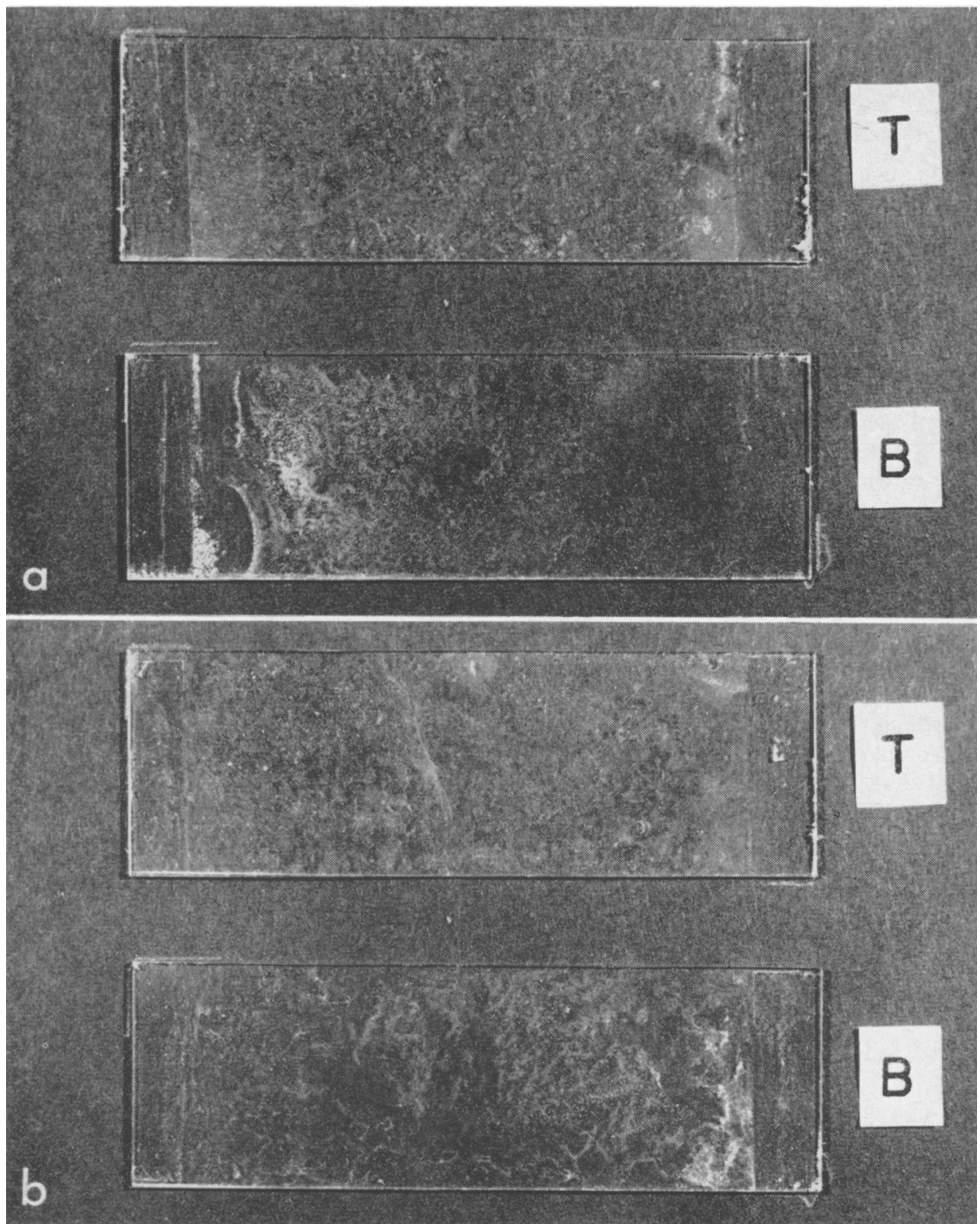

Fig. 2.-Spray deposits on microscope slides. "T" indicates slide taped on top of bottom slide "B." $\mathrm{a}=$ Standard high-volume ground application (1961).

$\mathrm{b}=$ Low-volume ground application (1961). 
surfaces of the slides than on the bottom surfaces, the total deposits on both sides were almost identical for the two types of applications (fig. 2a, b).

No difference was noted in the total deposits on the slides at various levels in the trees when the fixed-wing aircraft was used. However, this method of spraying produced almost no deposits on the bottom slide surfaces and less than one-half the deposits on the top slide surfaces compared to the ground applications (table 2 ; fig. 2 ).

Deposits on Leaves. Deposits

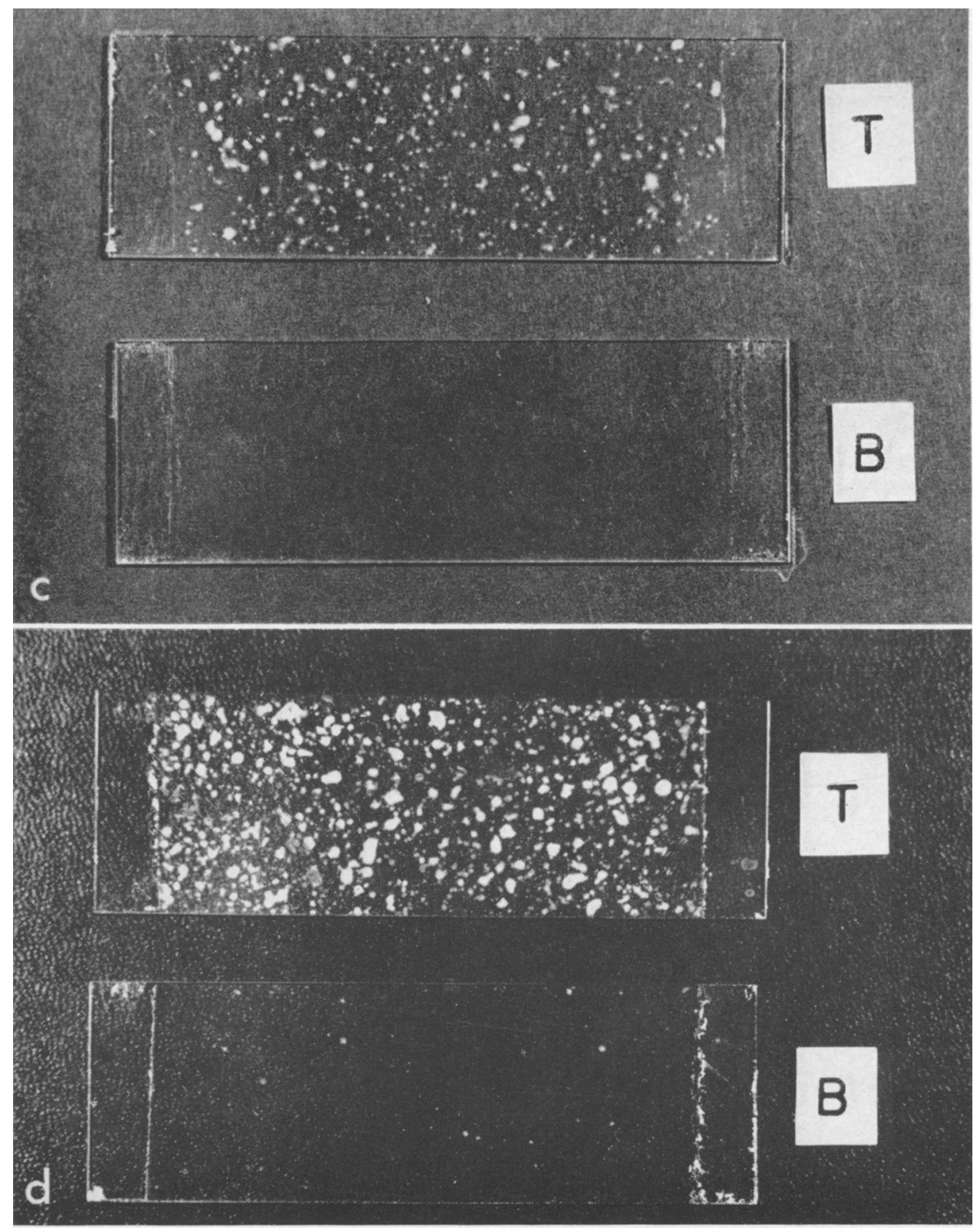

$\mathrm{c}=$ Fixed-wing aircraft application (1961).

$\mathrm{d}=$ Helicopter aircraft application (1962). 
TABLE 2

CAPTAN DEPOSITS ON MICROSCOPE SLIDES, 1961

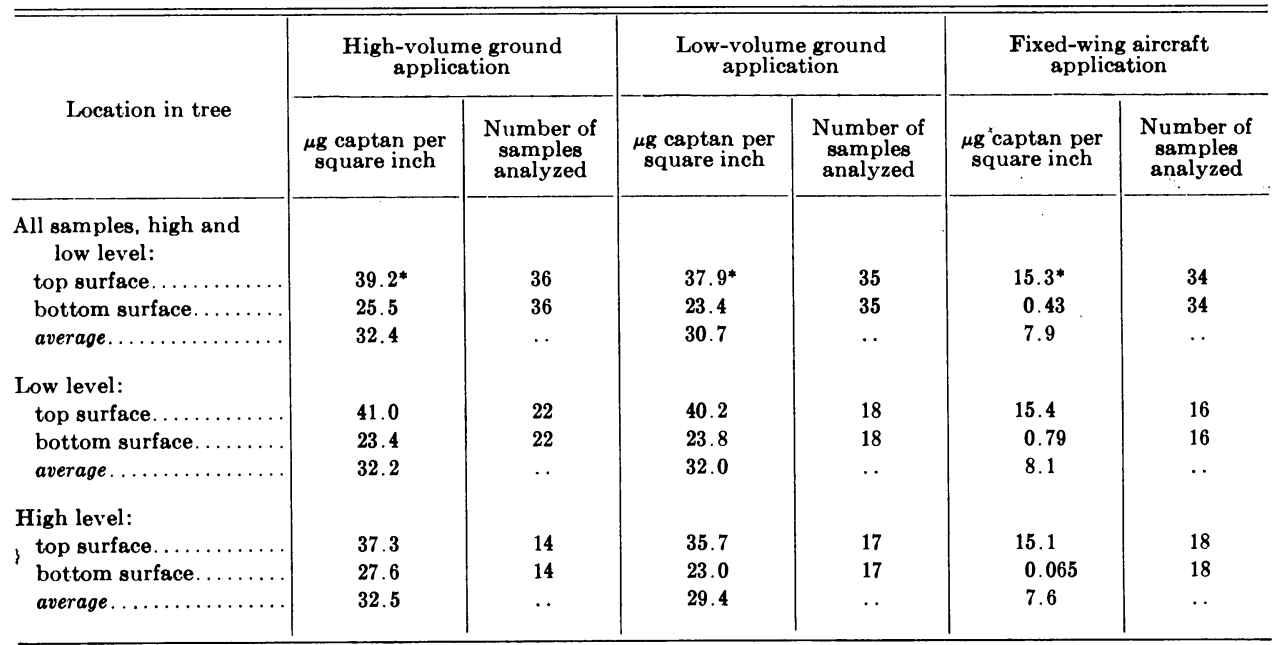

* Figures corrected for an application rate of 4.0 pounds of captan per acre; see table 1 for actual application rate.

TABLE 3

CAPTAN DEPOSITS ON LEAVES, 1961

\begin{tabular}{c|c|c|c}
\hline $\begin{array}{c}\text { Method of } \\
\text { application }\end{array}$ & $\begin{array}{c}\text { Number } \\
\text { of } \\
\text { samples } \\
\text { analyzed }\end{array}$ & $\begin{array}{c}\text { Average } \\
\text { deposit, in } \\
\text { parts per } \\
\text { million }\end{array}$ & $\begin{array}{c}\text { Average } \mu \mathrm{g} \\
\text { per square } \\
\text { inch }\end{array}$ \\
\hline $\begin{array}{r}\text { Fixed-wing aircraft... } \\
\text { Low-volume ground } \\
\text { sprayer............ }\end{array}$ & 12 & $223.5^{*}$ & 12.9 \\
$\begin{array}{r}\text { High-volume ground } \\
\text { sprayer............. }\end{array}$ & 12 & 656.1 & 38.0 \\
\hline
\end{tabular}

* Figures corrected for an application rate of 4.0 pounds of captan per acre; see table 1 for actual application rate.

leaves resulting from the two types of ground applications were not significantly different, although 19.5 times more volume of material (with a theoretical constant of 4.0 pounds active captan per acre) was applied by standard high-rolume procedure than by lowvolume spraying technique (table 3 ). However, the fixed-wing aircraft deposited less than one-half the amount of chemical deposited by the low-volume ground sprayer, even though the volume of spray was approximately the same. Thus, adequate coverage of the almond leaves at this particular stage of growth is possible with an application rate as low as 24 gallons per acre only when ground spraying equipment is used.

A partial explanation for the low leaf residues from the fixed-wing aircraft application is evident from the slide deposit data (table 2 ); these indicate very low deposits on the lower surfaces. Additionally, the photograph of spray deposits on the microscope slides shows almost no deposit on the bottom slide surfaces (fig. 2c). Apparently the aircraft failed to provide enough air turbulence to deposit spray on the lower leaf surfaces, whereas ground equipment directed spray onto both upper and lower leaf surfaces.

Disease Control Studies. Disease control data further substantiate the microscope slide and leaf deposit information. Table 4 shows that on the first date of evaluation no significant differences in the control of Coryneum blight was evident between the high and lowvolume ground applications. The ground applications produced significant Coryneum blight control, but the fixed-wing aircraft failed to do so. On the May 5 evaluation all treatments showed significant control, and the June 30 evaluation showed no significant difference in control between any of the treatments 
TABLE 4

DISEASE CONTROL OF CORYNEUM BLIGHT AND HENDERSONIA LEAF BLIGHT BY SPRAY APPLICTIONS, 1961

\begin{tabular}{|c|c|c|c|c|}
\hline \multirow{3}{*}{ Method of application } & \multicolumn{3}{|c|}{ Coryneum blight } & $\begin{array}{l}\text { Hendersonia } \\
\text { leaf blight }\end{array}$ \\
\hline & \multicolumn{3}{|c|}{ Average per cent infection per replication } & \multirow{2}{*}{$\begin{array}{c}\text { Average number } \\
\text { of blighted leaves } \\
\text { per replication } \\
\text { on June } 30 \S\end{array}$} \\
\hline & On leaf April 6* & On leaf May $5^{*}$ & On fruit June $30 \ddagger$ & \\
\hline Low-volume ground sprayer... & $11.3 \mathrm{AB} \dagger$ & $30.0 \mathrm{~A}$ & $30.0 \mathrm{~A}$ & $47.0 \mathrm{~A}$ \\
\hline Fixed-wing aircraft. . . . . . . & $24.7 \mathrm{BC} \dagger$ & $47.0 \mathrm{~A}$ & $28.3 \mathrm{~A}$ & $72.3 \mathrm{AB}$ \\
\hline Untreated control.... & $33.3 \mathrm{C} \dagger$ & $80.0 \mathrm{~B}$ & $52.3 \mathrm{~A}$ & $84.0 \mathrm{~B}$ \\
\hline
\end{tabular}

* 400 and 800 leaves inspected on first and second examination respectively on each of three replications. $\dagger$ Significance at 5 per cent level. Significance of mean comparisons was calculated by using the Duncan's multiple
range test. Means followed by letter "A" are significantly different from those not having "A"; those followed by "B" range test. Means followed by letter "A" are significantly
are significantly different from those not having "B," etc.

$\ddagger 100$ fruit surfaces inspected on each of three replications.
$\$ 10$, etc.

$\$$ Twenty 20 -inch shoots inspected on each of three replications.

and the check. These last results can be attributed to short residual life of cap$\tan$.

The results on Hendersonia leaf blight control again show that both ground applications gave equal control. Although the incidence of disease was considerably lower in the plots receiving the fixed-wing aircraft application than in the untreated check, the difference was not significant.

Table 4 data show that no differences in control exist between the high and low-volume ground applications. The fixed-wing application appears to afford some reduction in disease, but this can be substantiated only through larger scale test plots.

\section{Experiments in 1962}

Results in 1961 indicated that the concentrate application (24 gallons per acre) with the ground air-carrier sprayer was statistically as effective as the dilute ground application (467 gallons per acre). However, the fixed-wing aircraft application produced only about one-half the deposit obtained when the low-volume or high-volume ground spraying procedures were used. In view of these data, the 1962 project was expanded to include a helicopter application in an effort to determine a more effective aerial application technique. The helicopter application was conducted at a low forward speed to determine if a high degree of air circulation and turbulence would result in spray coverage superior to that from fixed-wing aircraft applications. All treatments and checks were replicated three times. To assure a minimum of contamination of other areas by air applications, a block of 60 trees $(5 \times 12)$ was treated, with three central trees in each block being utilized for coverage measurements.

Deposits on Microscope Slides. Table 5 shows that when the high-volume ground sprayer was used, approximately equal amounts of captan were found on the top and the bottom surfaces of the slides. Slightly more deposit was present on slides in the upper levels of the trees than on slides in the lower levels. Even though every precaution possible was taken to duplicate the exact spray conditions used in 1961, some variations in deposits were evident in the 1962 experiments. Comparing the high-volume ground spray applications made in 1961 and 1962 (tables 2 and 5), it is evident that substantially more deposit was obtained in 1961 than in 1962. This difference could be due, in part, to the high wind velocity (11.1 $\mathrm{mph}$ ) 
TABLE 5

CAPTAN DEPOSITS ON MICROSCOPE SLIDES, 1962

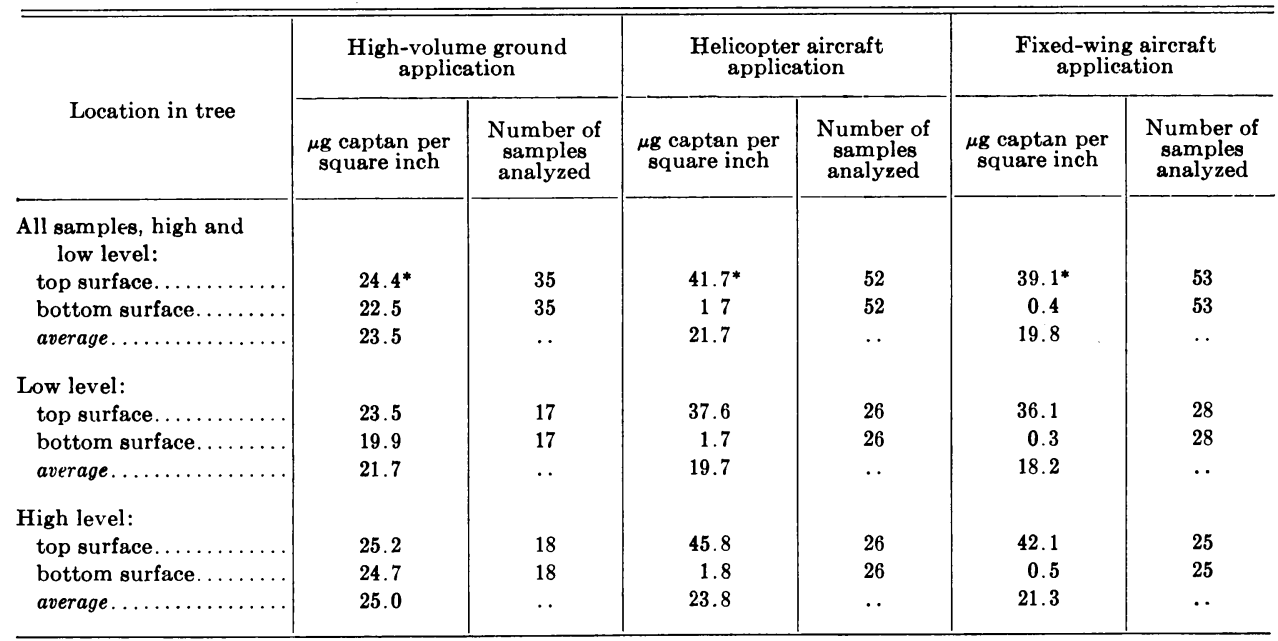

* Figures corrected for an application rate of 4.0 pounds of captan per acre; see table 1 for application rate.

encountered in 1962 when the spray was applied. However, results obtained during the 2-years' study show that the high-volume ground sprayer applications deposited significant quantities of fungicide on both the upper and lower surfaces of the slides regardless of their positions in the trees.

The fixed-wing aircraft application again produced noticeably low deposits on the bottom surfaces. However, more deposits were obtained on the top surfaces this year compared to the 1961 fixed-wing aircraft application; this deposit was even greater than in the 1962 high-volume application. During the application of the high-volume spray,

TABLE 6

CAPTAN DEPOSITS ON LEAVES, 1962

\begin{tabular}{c|c|c|c}
\hline $\begin{array}{c}\text { Method of } \\
\text { application }\end{array}$ & $\begin{array}{c}\text { Number } \\
\text { of } \\
\text { samples } \\
\text { analyzed }\end{array}$ & $\begin{array}{c}\text { Amount of } \\
\text { captan, in } \\
\text { parts per } \\
\text { million }\end{array}$ & $\begin{array}{c}\text { Average } \mu \mathrm{g} \\
\text { per square } \\
\text { inch }\end{array}$ \\
\hline $\begin{array}{r}\text { Fixed-wing aircraft. } \\
\text { Helicopter........... }\end{array}$ & 17 & 270.8 & 15.7 \\
$\begin{array}{r}\text { High-volume ground } \\
\text { sprayer........... }\end{array}$ & 16 & 308.1 & 15.0 \\
\hline
\end{tabular}

Corrected for application rate of 4.0 pounds captan per acre; see table 1 for application rate. there was an $11 \mathrm{mph}$ wind and this could partly explain the lower deposits. An increase in deposits with the fixed-wing aircraft in 1962 could be explained by the use of a different aircraft and operator. Nevertheless, the data do indicate that the fixed-wing aircraft spray deposits result largely from direct gravitational fall of the particles onto the upper surfaces.

The helicopter treatment, occurring under more favorable conditions (5.2 mph wind velocity), produced greater deposits on the top surfaces of the slides, but deposits on the bottom surfaces were only 7.5 per cent of the amount produced on the bottom surfaces by the high-volume ground sprayer. The helicopter application did show a slight increase in bottom coverage (from 0.4 to 1.7 micrograms psi) over that obtained with the fixed-wing aircraft, although it is not apparent from the photographs of the slides (fig. 2d). A finer particle size (plus the increased air circulation created by the low forward speed of the helicopter) might give a higher deposit on the bottom surfaces of the slides and leaves. 
Deposits on Leaves. With all types of applications, the deposits on leaves (table 6) were slightly lower than the deposits on the glass slides. Fixed-wing and helicopter applications resulted in less chemical per square inch of leaf surface than did applications from the high-volume ground sprayer. Thus, as in 1961, leaf deposit data substantiated the microscope slide studies conducted during this year.

Disease Control Studies. The degree of infection of the two diseases under study was not substantial in 1962 and the small differences between the control and the test plots were not significant.

\section{SUMMARY AND CONCLUSIONS}

A 2-year study was conducted to determine the extent of disease control (Coryneum blight and Hendersonia leaf blight) and coverage efficiency of lowvolume (concentrate) sprays of captan applied to almond trees at petal-fall and 1. week after petal-fall stage of bloom. Results were compared with data obtained by the standard high-volume ground spraying technique. Three methods of concentrate spray applications were used: the fixed-wing aircraft method, the helicopter aircraft method, and the low-volume ground method.

Studies of the three methods of concentrate spray applications compared to the standard high-volume ground applications produced the following results:

1. The microscope slide technique used proved to be an excellent measure of the spray coverage for each of the methods tested when compared to disease performance data and captan deposits on leaves.

2. With each method tested, deposits on the slides placed in the upper levels of the trees were approximately the same as those placed in the lower levels.

3. Spray coverages resulting from high-volume and low-volume ground applications produced large deposits on both the upper and lower surfaces of the microscope slides.

4. Spray coverage resulting from the fixed-wing aircraft method indicated that large deposits were on the upper surfaces of the slides, but that only trace amounts were present on the lower surfaces.

5. Spray coverage resulting from the helicopter aircraft method indicated that again large deposits were on the upper surface of the slides, and that more deposits were on the lower surfaces compared to the fixed-wing aircraft method.

6. The low and high-volume ground spray applications gave equal control of Coryneum blight and Hendersonia leaf blight. Although the incidence of disease was considerably lower than in the untreated check, the fixed-wing aircraft application gave no significant control of Hendersonia leaf blight. It did show, however, some control of Coryneum blight. The helicopter application could not be evaluated for disease control because of the low incidence of the two leaf diseases in 1962. 


\section{ACKNOWLEDGMENTS}

The authors wish to acknowledge the assistance of the following organizations for their contributions to this study: California Chemical Company, Richmond, California for supplying the captan; Berylwood Investment Company, Gridley, California for furnishing the blower sprayer; Aeronock, Incorporated, Gridley, California for the 1961 fixed-wing aircraft application; Onstott Dusters, Yuba City, California for the 1962 fixed-wing aircraft application; Stockton Helicopters, Stockton, California for the 1962 helicopter aircraft application.

We also thank Mr. Kin Wa Cheng for his technical assistance.

\section{LITERATURE CITED}

California Spray-Chemical Corporation.

1960. Residue method RM-1. The analysis of residues of captan and phalton.

Ogawa, J. M., E. E. Wilson, and Harley English.

1959. The leaf blight disease of almond and its control. Hilgardia 28: 239-54.

Ogawa, J. M., and W. E. Yates.

1962. Effect of volume and variation in droplet size of spray applications from an air-carrier sprayer on control of three almond diseases. Plant Disease Reptr. 46: 614-15.

O'ReIlly, H. J.

1957. Relative efficiency of airplane and ground application of sprays in controlling almond shot-hole disease. Phytopathology 47: 530. 

The journal HILGARDIA is published at irregular intervals, in volumes of about 650 to 700 pages. The number of issues per volume varies.

Single copies of any issue may be obtained free, as long as the supply lasts; please request by volume and issue number from:

\author{
Agricultural Publications \\ University Hall \\ University of California \\ Berkeley, California 94720
}

The limit to nonresidents of California is 10 separate titles. The limit to California residents is 20 separate titles.

The journal will be sent regularly to libraries, schools, or institutions in one of the following ways:

1. In exchange for similar published material on research.

2. As a gift to qualified repository libraries only.

3. On a subscription basis- $\$ 7.50$ a year paid in advance. All subscriptions will be started with the first number issued during a calendar year. Subscribers starting during any given year will be sent back numbers to the first of that year and will be billed for the ensuing year the following January. Make checks or money orders payable to The Regents of The University of California; send payment with order to Agricultural Publications at above address. 